\title{
Infectivity and pathogenicity of the oomycete Aphanomyces invadans in Atlantic menhaden Brevoortia tyrannus
}

\author{
Yasunari Kiryu $^{1}$, Jeffrey D. Shields ${ }^{1, *}$, Wolfgang K. Vogelbein ${ }^{1}$, Howard Kator ${ }^{1}$, \\ Vicki S. Blazer ${ }^{2}$ \\ ${ }^{1}$ Department of Environmental and Aquatic Animal Health, Virginia Institute of Marine Science, Gloucester Point, \\ Virginia 23062, USA \\ ${ }^{2}$ National Fish Health Research Laboratory, Biological Resources Division, US Geological Survey, 1700 Leetown Road, \\ Kearneysville, West Virginia 25430, USA
}

\begin{abstract}
Atlantic menhaden Brevoortia tyrannus develop characteristic skin ulcers in response to infection by the oomycete Aphanomyces invadans. To investigate pathogenicity, we conducted a dose response study. Juvenile menhaden were inoculated subcutaneously with 0, 1, 5, 10, 100, and 500 secondary zoospores per fish and monitored for $37 \mathrm{~d}$ post-injection (p.i.). Survival rates declined with increasing zoospore dose, with significantly different survivorship curves for the different doses. Moribund and dead fish exhibited characteristic ulcerous lesions at the injection site starting at $13 \mathrm{~d}$ p.i. None of the sham-injected control fish (0 zoospore treatment) died. The $\mathrm{LD}_{50}$ (lethal dose killing $50 \%$ of exposed menhaden) for inoculated fish was estimated at 9.7 zoospores; however, some fish receiving an estimated single zoospore developed infections that resulted in death. Menhaden were also challenged by aqueous exposure and confirmed that $A$. invadans was highly pathogenic by this more environmentally realistic route. Fish that were acclimated to culture conditions for $30 \mathrm{~d}$, and presumably free of skin damage, then aqueously exposed to 100 zoospores $\mathrm{ml}^{-1}$, exhibited $14 \%$ lesion prevalence with $11 \%$ mortality. Net-handled fish that were similarly infected had a significantly higher lesion prevalence (64\%) and mortality (64\%). Control fish developed no lesions and did not die. Scanning electron microscopy of fish skin indicated that zoospores adhered to intact epidermis, germinated and penetrated the epithelium with a germ tube. Our results indicate that $A$. invadans is a primary pathogen of menhaden and is able to cause disease at very low zoospore concentrations.
\end{abstract}

KEY WORDS: Dose response $\cdot$ Epizootic ulcerative syndrome $\cdot \mathrm{LD}_{50} \cdot$ Lesions $\cdot$ Mortality $\cdot$ Secondary zoospores · Tissue repair · Ulcerative mycosis

Resale or republication not permitted without written consent of the publisher

\section{INTRODUCTION}

Atlantic menhaden Brevoortia tyrannus with deeply penetrating ulcerous skin lesions have been observed since the mid 1980s in mid-Atlantic United States estuaries (Hargis 1985, Dykstra et al. 1989, Noga et al. 1991, Noga 1993). Histologically, these lesions are characterized by severe myonecrosis and extensive granulomatous myositis associated with penetrating fungal hyphae (Noga et al. 1988, Noga 1993). Origi- nally, the condition, termed ulcerative mycosis (UM), was attributed to infection by oomycete water moulds of the genus Aphanomyces (Noga \& Dykstra 1986). Massive fish kills were reported to occur in North Carolina estuaries as a result of the disease (Dykstra et al. 1986, Noga \& Dykstra 1986). Environmental factors were believed to play an important role in outbreaks of the disease, with the oomycete agent likely being a secondary invader (Noga \& Dykstra 1986, Noga et al. 1988, Levine et al. 1990). 
Recently, the lesionous menhaden as well as acute fish kills have been attributed to the activity of the toxic dinoflagellates Pfiesteria piscicida and P. shumwayae (Burkholder et al. 1992, 1995, 2001, Noga et al. 1996, Glasgow et al. 2001). However, investigations of menhaden from Chesapeake Bay indicate that oomycete hyphae have high host specificity to menhaden, an association typical of an aetiological agent. The agent infecting menhaden from Chesapeake Bay was identified as Aphanomyces invadans (Blazer et al. 1999, 2002, Kiryu et al. 2002). A. invadans has been implicated as the causative agent of epizootic ulcerative syndrome (EUS) in Asia (Roberts et al. 1993, Lilley \& Roberts 1997, Catap \& Munday 1998), red spot disease (RSD) in Australia (Fraser et al. 1992, Callinan et al. 1989, 1995), and mycotic granulomatosis (MG) in Japan (Egusa \& Masuda 1971, Miyazaki \& Egusa 1972, 1973a,b,c, Hatai et al. 1977, Wada et al. 1994, 1996). It causes devastating losses to cultured fishes in India, Malaysia, Indonesia and Hong Kong (reviewed by Lilley et al. 1998). Gross and histopathologies of EUS have been well described (Roberts et al. 1993, Catap \& Munday 1998, Lilley et al. 1998) and are identical to that of UM in menhaden (Blazer et al. 1999, 2002, Kiryu et al. 2002).

Kiryu et al. (2002) experimentally induced the ulcerous lesions in menhaden by both inoculation and bath exposure with secondary zoospores of the endemic isolate of Aphanomyces invadans. They fulfilled Koch's postulates and demonstrated that $A$. invadans is the causative agent of UM in menhaden. However, in their injection study, zoospore doses were high, and not necessarily reflective of environmental exposure. The objectives of this study were: (1) to conduct a doseresponse study to determine an $\mathrm{LD}_{50}$ (lethal dose killing $50 \%$ of exposed menhaden) for secondary zoospores using inoculations, (2) to compare mortality of fish exposed to zoospores via inoculation or bath challenge, (3) to better assess the pathogenicity of $A$. invadans using formal survival analysis, (4) to examine the dynamics of gross alterations caused by the disease, and (5) to describe tissue repair in fish surviving exposure.

\section{MATERIALS AND METHODS}

Fish collection and maintenance. Atlantic menhaden were obtained from 2 sources. Fish used in the zoospore injection trials (Age-class 1; $\mathrm{n}=134$; mean weight $13.4 \mathrm{~g}$, range 3.2 to $27.8 \mathrm{~g}$; mean total length $113 \mathrm{~mm}$, range 71 to $144 \mathrm{~mm}$ ) were collected from upper Chesapeake Bay tributaries. Fish used in aqueous exposures (Age-class 1; $\mathrm{n}=78$; mean weight $9.3 \mathrm{~g}$, range 2.4 to $26.2 \mathrm{~g}$; mean total length $97 \mathrm{~mm}$, range
69 to $141 \mathrm{~mm}$ ) were collected by cast net from Sarah Creek, York River, Virginia. Fish were held in a static recirculating system consisting of $2 \times 712 \mathrm{l}$ fiberglass tanks containing filtered $(35 \mu \mathrm{m})$ York River water diluted to $12 \mathrm{psu}(=\%)$ at temperatures between 20 and $23^{\circ} \mathrm{C}$ (injection trials), or held under ambient conditions (salinity 20 to $24 \mathrm{psu}_{\text {; }}$ temperature 25 to $28^{\circ} \mathrm{C}$ ) (aqueous exposures). Water changes (25\%) in maintenance aquaria and experimental treatments were performed weekly to maintain water quality. Fish were fed a daily diet of algal paste, supplemented with HiPro 0.5GR Debut Corey Starter (Corey Feed Mills).

Oomycete culture and sporulation. Aphanomyces invadans, WIC strain, an endemic strain isolated from a lesionous menhaden in Wicomico River, Maryland (see Blazer et al. 1999), was used in this study. Culture characteristics and methods of sporulation have been previously described (Kiryu et al. 2002). Zoospore densities were estimated with a haemacytometer (Neubauer/Bright-Line) using samples fixed with 10\% neutral-buffered formalin.

Zoospore inoculations. Fish were acclimated for $4 \mathrm{~d}$ in $10 \times 76 \mathrm{l}$ glass aquaria ( 9 to 15 fish per tank) containing 6 psu artificial seawater (ASW, Marinemix Forty Fathoms) and maintained at room temperature (daily mean $21.6 \pm 0.61^{\circ} \mathrm{C}$ ). Tanks were equipped with 2 Whisper filters (Tetra/Second Nature) containing a preconditioned filter bag filled with crushed coral. Fish were lightly anaesthetised in $75 \mathrm{mg} \mathrm{l}^{-1}$ tricane methanesulfonate (MS-222) and inoculated with $0.1 \mathrm{ml}$ of a zoospore suspension to deliver $1,5,10,100$, or 500 zoospores per fish. Each fish was injected subcutaneously using a 27 gauge, $12.7 \mathrm{~mm}$ needle and $1 \mathrm{ml}$ syringe on the left flank. Control fish were injected with $0.1 \mathrm{ml}$ sterile water (1 psu). Two replicate tanks were assigned to each treatment, except for the 100 and 500 zoospores per fish treatments, which were not replicated. To confirm oomycete viability, $0.1 \mathrm{ml}$ of each inoculum was plated in triplicate onto glucose peptone-penicillin-oxolinic acid agar (GP-POX agar; Willoughby \& Roberts 1994, Lilley et al. 1998). Hyphal growth in all treatments indicated viabile zoospores within each dose. Fish were monitored and fed daily for 37 d. Dissolved oxygen (DO), pH (Orion 290A), ammonia (Hach), and nitrite (Hach) concentrations were monitored weekly. Water quality parameters ranged from 6.4 to $7.7 \mathrm{mg} \mathrm{l}^{-1} \mathrm{DO}, \mathrm{pH} 6.8$ to $8.0,0.2$ to $8.0 \mathrm{mg} \mathrm{l}^{-1}$ total ammonia, and 0.0 to $16.0 \mathrm{mg} \mathrm{l}^{-1}$ nitrite. The absence of Pfiesteria-like dinoflagellates was confirmed by microscopic examination of $25 \mathrm{ml}$ of tank water fixed with Lugol's iodine.

Aqueous exposure. Fish (6 to 18 per tank) were acclimated for $>30 \mathrm{~d}$ in $6 \times 76 \mathrm{l}$ glass aquaria containing 20 psu ASW, each equipped with a preconditioned Whisper filter. Each tank was held at room tempera- 
ture (daily mean $19.2 \pm 1.09^{\circ} \mathrm{C}$ ). Fish in the 6 aquaria were assigned to 3 treatments of 2 replicates each: (1) net-stress aqueous exposure; (2) untraumatized aqueous exposure; and (3) unexposed control. Menhaden have deciduous scales. Therefore, fish in the net-stress treatment experienced minor loss of scales with epidermal abrasion, providing a portal of entry for the water mould.

For all treatments, salinity was gradually lowered from 20 psu to 1 psu over a $30 \mathrm{~d}$ period. Salinities of 2 psu or less are required for sporulation, motility, and infectivity of Aphanomyces invadans (Blazer et al. 2002). Once acclimated, fish were held at $1 \mathrm{psu}$ for $24 \mathrm{~h}$ before exposure. For all treatments, the volume of each tank was lowered to $30 \mathrm{l}$, and filtration was turned off during the exposure $(5.5 \mathrm{~h})$. For Treatment 1 , fish in each tank were captured and held in a net for $30 \mathrm{~s}$ (netstress), zoospores were then added to the aquaria to give an estimated concentration of 100 zoospores $\mathrm{ml}^{-1}$. For Treatment 2, fish remained undisturbed (untraumatized), and zoospores were added to the aquaria to give an estimated density of 100 zoospores $\mathrm{ml}^{-1}$. The control (Treatment 3) consisted of the same protocol as Treatment 2, except that sterile water (1 psu) was added instead of zoospores. Fish in Treatments 1 and 2 were exposed to zoospores for $5.5 \mathrm{~h}$ (with aeration only). Viability was confirmed during the exposure period by microscopically examining water samples for zoospore motility. Exposure was stopped by adding 12 psu ASW to each tank, raising the salinity to 6 psu, which inhibited zoospore motility (Blazer et al. 2002). Fish in all treatments were monitored daily for $27 \mathrm{~d}$ and fed as described above. Water samples were devoid of dinoflagellates.

Gross examination and histological processing. Aquaria were monitored at least twice daily, and dead and moribund fish were removed. All of the fish were weighed, measured (total length), examined for gross pathology, and selected fish were photographed. For the injection study, the fish were cut in half transversely at the lesion or injection site to examine the gross pathology. The area of each lesion was calculated using the simple equation for a rectangle. In the inoculation experiment, all moribund fish and fish surviving to the end of the experiment were examined histologically. In the aqueous exposure, only moribund fish with ulcers and fish surviving to the end of the trial were examined histologically. Fish were killed by overdose with MS-222 and fixed in 10\% neutralbuffered formalin. Tissues were decalcified with formic acid-sodium citrate solution (Luna 1968) prior to processing for histology. For fish exhibiting lesions, 2 different areas, approximately 4 to $5 \mathrm{~mm}$ apart within the lesion site, were examined. All slides were stained with Harris' haematoxylin and eosin (H\&E; Luna 1968).
Selected slides were stained with Grocott's methenamine-silver nitrate (GMS) to demonstrate oomycetous hyphae, or Masson's trichrome (MT) to demonstrate collagen fibrils in the tissues (Luna 1968).

Scanning electron microscopy. Juvenile menhaden were killed by overdose with MS-222 and moved into a $50 \mathrm{ml}$ culture flask containing $1.10 \times 10^{4} \mathrm{cells} \mathrm{ml}^{-1}$ secondary zoospores. The fish were incubated with zoospores for $3 \mathrm{~h}$, then removed by the caudal fin and fixed overnight at $4{ }^{\circ} \mathrm{C}$ with modified Karnovsky solution $(4 \%$ paraformaldehyde and $5 \%$ gultaraldehyde in $0.1 \mathrm{M}$ sodium cacodylate buffer without $\mathrm{CaCl}_{2}$, at $\mathrm{pH}$ 7.4). Samples were rinsed in 3 changes of $0.1 \mathrm{M}$ sodium cacodylate buffer at room temperaure, postfixed with $1 \% \mathrm{OsO}_{4}$ for $1 \mathrm{~h}$, and rinsed 3 times with the buffer solution. Samples were then dehydrated through a graded ethanol series, critical point-dried (Polaron Model E3100), mounted on an aluminum stub (Ted Pella), and sputter-coated with $20 \mathrm{~nm}$ of $\mathrm{Au}: \mathrm{Pd}$ (Anatech Hummer VII). Tissues were examined with a scanning electron microscope (Leo $435 \mathrm{VP}$ ).

Statistical analyses. The LIFEREG model (SAS Institute 1989), with the accelerated failure time model (Lee 1992, Cantor 1997) was used for censored survival analysis. The LIFEREG statistic is reported as a logrank chi-square. Five different survival models (exponential, Weibull, Gamma, log-normal, or log-logistic) were examined for best fit, followed by testing with the model $y=$ dose or $y=$ treatment with the best-fitted model. Because no control fish died during the course of study in both injection and aqueous exposure, controls were excluded from the LIFEREG analyses. Lesion area was also analyzed by LIFEREG with the model $y=$ area separated by dose with the best-fitted model. Normal maximum-likelihood estimates of $\mathrm{LD}_{50}$ and the $95 \%$ CIs at $37 \mathrm{~d}$ post-injection (p.i.) were calculated using a probit model (SAS Institute 1989), $\Phi^{-1}(x)=\alpha+$ $\beta x+5$, where $\Phi^{-1}(x)=$ cumulative distribution of mortality for the standard normal distribution; $\alpha=$ estimated parameter for the intercept; $\beta=$ estimated parameter for the slope; and $x=\log _{10}($ dosage $)$.

\section{RESULTS}

\section{Survival}

Survivorship decreased in relation to increasing zoospore dose (Table 1). In most cases, fish that developed frank ulcers died shortly thereafter. Fish that did not develop ulcers possessed numerous granulomas histologically, and often showed signs of significant tissue repair around the inoculation site. Fish began dying $13 \mathrm{~d}$ after inoculation with zoospores (Fig. 1). Mean mortality rates per day (\%) starting after $13 \mathrm{~d}$ 
Table 1. Brevoortia tyrannus. Relationships between Aphanomyces invadans dosage and survivorship, percentage of fish exhibiting lesions (both ulcers and tissue repair/healing), percentage of fish without lesions, and percentage of fish dying with ulcerous lesion within $37 \mathrm{~d}$ post injection with secondary zoospores of A. invadans. Granulomas and tissue repair were confirmed histologically. All fish exhibiting ulcers died or became moribund, with the exception of 1 fish that was injected with 5 zoospores per fish. All fish exhibiting tissue repair did not develop ulcers; i.e. they were surviving fish with lesions

\begin{tabular}{|c|c|c|c|c|c|c|c|c|c|}
\hline \multirow{2}{*}{$\begin{array}{l}\text { Dose (zoospores } \\
\text { per fish) }\end{array}$} & \multirow[t]{2}{*}{$\mathrm{n}$} & \multirow[t]{2}{*}{ Survivorship } & \multicolumn{3}{|c|}{ \% fish exhibiting } & \multicolumn{2}{|c|}{ Surviving fish with no lesions } & \multicolumn{2}{|c|}{ Dead fish } \\
\hline & & & Lesions & Ulcers & Tissue repair & $\mathrm{n}$ & $\%$ granulomas & & $\%$ ulcer \\
\hline 0 & 18 & 100 & 0 & 0 & 0 & 18 & - & 0 & - \\
\hline 1 & 29 & 76 & 31 & 21 & 10 & 19 & 21 & 7 & $86^{\mathrm{a}}$ \\
\hline 5 & 30 & 57 & 53 & 47 & 7 & 14 & 50 & 13 & 100 \\
\hline 10 & 28 & 43 & 64 & 57 & 7 & 10 & 50 & 16 & 100 \\
\hline 100 & 14 & 36 & 86 & 64 & 21 & 2 & 100 & 9 & 100 \\
\hline 500 & 15 & 13 & 93 & 80 & 13 & 0 & - & 13 & $92^{\mathrm{b}}$ \\
\hline
\end{tabular}

p.i. were $1.0 \% \mathrm{~d}^{-1}\left(1\right.$ zoospore treatment), $1.8 \% \mathrm{~d}^{-1}$ (5 zoospore treatment), $2.4 \% \mathrm{~d}^{-1}(10$ zoospore treatment), $2.7 \% \mathrm{~d}^{-1}(100$ zoospore treatment), and $3.6 \%$ $\mathrm{d}^{-1}$ (500 zoospore treatment). The log-normal distribution was the best-fit curve for survivorships with LIFEREG analysis ( $\log$ likelihood $=-82.449$ ). The shape of the survivorship curves was not different among menhaden inoculated with 5, 10, and 100 zoospores per fish (Fig. 1). The survivorship of fish inoculated with 1 zoospore was significantly higher than other treatments, except for that from fish inoculated with 5 zoospores (log-rank chi-square, p < 0.05). The survivorship of fish inoculated with 500 zoospores was significantly $(p<0.05)$ lower than that of fish injected with 1, 5, 10, and 100 zoospores (Fig. 1). None of the sham-injected control fish died during the study.

Aphanomyces invadans was highly pathogenic when injected into menhaden. The $\mathrm{LD}_{50}$ over the $37 \mathrm{~d}$ period was estimated as 9.73 zoospores per fish $195 \%$ CI 3.55 to 27.86 zoospores per fish) by Probit analysis (Fig. 2).

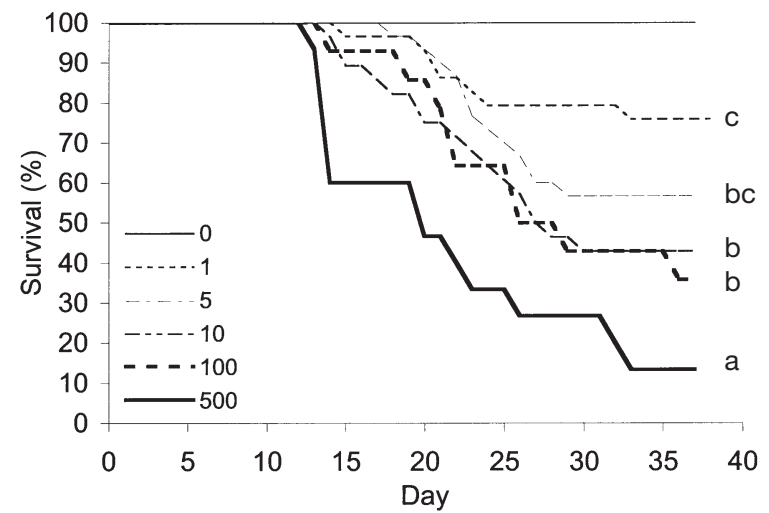

Fig. 1. Brevoortia tyrannus. Survival of fish inoculated with different doses of zoospores of Aphanomyces invadans. Significant differences $(\mathrm{p}<0.05)$ in shape of the survivorship curves (LIFEREG analysis) are indicated by the letters $a$, b, and $c$
Survivorship of fish exposed to zoospores in untraumatized and net-stress treatments was 89 and $36 \%$, respectively (Table 2). None of the control fish died during the experiment. The mean daily mortality rate was $0.4 \% \mathrm{~d}^{-1}$ (untraumatized) and $2.4 \% \mathrm{~d}^{-1}$ (netstress). Survivorship among the treatments was best fit by a log-normal distribution (log likelihood $=-39.571$ ), and the survivorship of net-handled fish was significantly lower than that of untraumatized fish (LIFEREG analysis, log-rank chi-square, $\mathrm{p}<0.01$; Fig. 3).

\section{Gross pathology}

Inoculation study

Immediately after inoculation, during recovery from anaesthesia, some fish, including sham-injected controls, exhibited reddening at the injection site. In control fish, the reddening at the injection started to disappear around $2 \mathrm{~d}$ p.i., and was not grossly visible at $7 \mathrm{~d}$ p.i. For

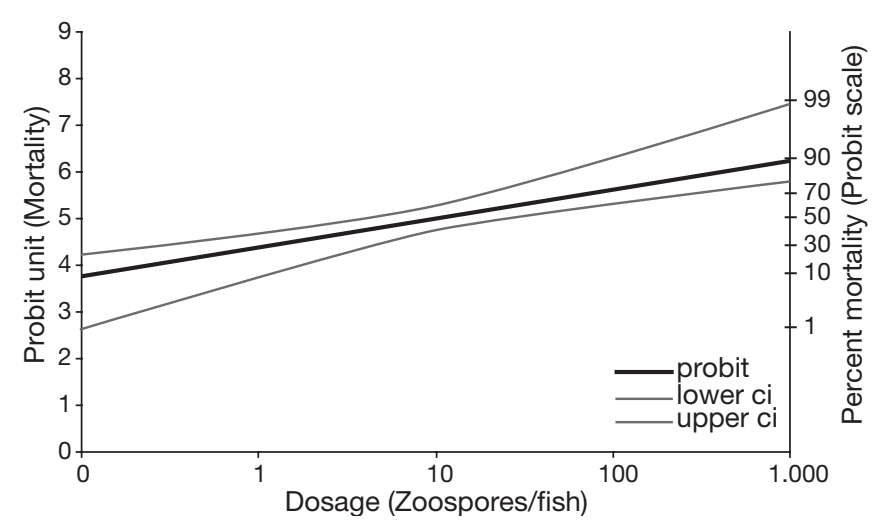

Fig. 2. Brevoortia tyrannus. Mortality curve (Probit), with 95\% upper and lower CIs at $37 \mathrm{~d}$ post-injection, used to estimate the $\mathrm{LD}_{50}$ of 9.7 zoospores per fish 
Table 2. Brevoortia tyrannus. Mortality and prevalence of the lesions developing over $27 \mathrm{~d}$ in menhaden following aqueous exposure to secondary zoospores (100 zoospores $\mathrm{ml}^{-1}$, exposure duration $5.5 \mathrm{~h}$ ) of Aphanomyces invadans

\begin{tabular}{|lcccc|}
\hline Treatment & $\mathrm{n}$ & \multicolumn{3}{c|}{\begin{tabular}{c} 
\% fish exhibiting \\
\cline { 3 - 5 }
\end{tabular}} \\
& & $\begin{array}{c}\text { Survivorship } \\
(\%)\end{array}$ & $\begin{array}{c}\text { Diffuse } \\
\text { reddening } \\
\text { lesions }\end{array}$ & $\begin{array}{c}\text { Focal } \\
\text { ulcerous } \\
\text { lesions }\end{array}$ \\
\hline Net-stress & 14 & 36 & 29 & 64 \\
Untraumatized & 36 & 89 & 6 & 14 \\
Control & 28 & 100 & 0 & 0 \\
\hline
\end{tabular}

fish inoculated with zoospores, incipient ulcerous lesions were first visible at $5 \mathrm{~d}$ p.i., and became more apparent after $7 \mathrm{~d}$ p.i. The number of fish developing lesions increased with dosage (Table 1). All of the fish exhibiting necrotic ulcerous lesions died or became moribund, with the exception of 1 fish inoculated with 5 zoospores (exhibiting a $9 \times 14 \mathrm{~mm}$ ulcerous lesion) which survived for the duration of the experiment ( $37 \mathrm{~d}$ ).

Grossly, a single focal necrotic lesion occurred at the injection site of each fish regardless of zoospore dose. The size of the lesion (range: $3 \times 4$ to $14 \times 29 \mathrm{~mm}$; maximum elevation $6 \mathrm{~mm} ; 1$ to $10 \mathrm{~mm}$ penetrating into tissue) was not related to the dose; fish that were administered 1 zoospore developed large ulcers (Fig. 4a,b). Sloughing of necrotic tissues frequently occurred after $22 \mathrm{~d}$ p.i. (Fig. 4c). The area of the lesion was positively correlated with fish mortality in the 1, 5, and 10 zoospores treatments (LIFEREG, p $<0.01$ ). However, there were no significant associations with time nor with lesion size for fish in the 100 and 500 zoospores treatment. All dead and moribund fish exhibited necrotic ulcerous lesions, except for 2 fish; 1 fish (treatment: 1 zoospore) died without developing lesions and without showing a histologically confirmed granulomatous response; another fish (treatment: 500 zoospores) died without developing a lesion, but

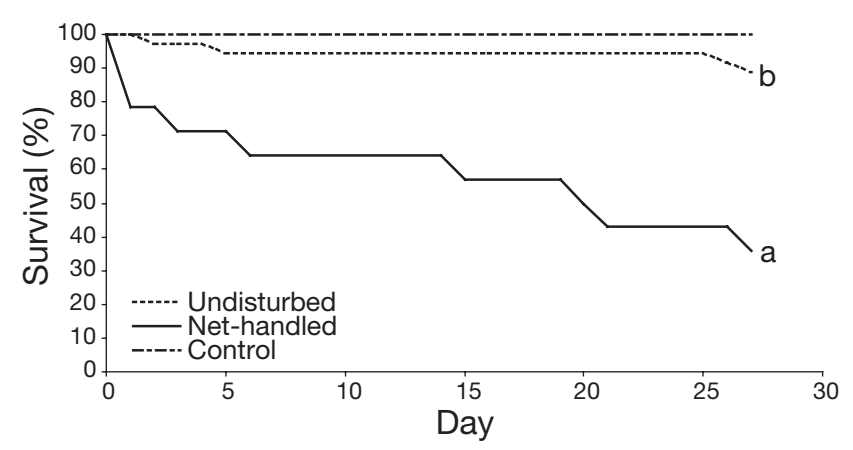

Fig. 3. Brevoortia tyrannus. Survival of fish exposed to zoospores of Aphanomyces invadans in bath challenges. Significant differences $(p<0.05)$ in shape of the survivorship curves (LIFEREG analysis) are indicated by the letters a and $b$ with a moderate granulomatous response. Between 18 and $37 \mathrm{~d}$ p.i., multifocal necrotic ulcerous lesions (usually 2 to 3 areas on left side trunk including the injection site) were observed in $7 \%$ of fish administered 10 zoospores, $21 \%$ of fish administered 100 zoospores, and $20 \%$ of fish administered 500 zoospores. Two of these fish (1 each from 10 or 500 zoospore treatments) also had ulcerous lesions involving the vent area (Fig. 4c).

Lesions exhibited histological features indicative of tissue repair (for histopathology, see subsection below). Tissue repair was observed microscopically in 7 to $21 \%$ of the fish that were injected with zoospores (Table 1). At $37 \mathrm{~d}$ p.i., 2 stages in the tissue repair process were observed. The first, presumably early, stage was seen in 4 fish inoculated with more than 5 zoospores per fish. Grossly, the focal lesion (approximately $1 \times 1$ to $7 \times 7 \mathrm{~mm}, 1$ to $2 \mathrm{~mm}$ elevation) appeared red, raised, granular, shiny, and had a gritty surface (Fig. $4 \mathrm{~d}$ ). The cut appearance of the lesion was pink at the center, demarcated from normal skeletal muscle tissue and penetrated 1 to $4 \mathrm{~mm}$ into the tissue from the external surface. The second, presumably more advanced, stage was seen in 9 fish from all of the fish inoculated with more than 1 zoospore treatment. Grossly, a focal, concave, translucent lesion (approximately $6 \times 7 \mathrm{~mm}$ ) was observed (Fig. 4e). However, the cut appearance of the skeletal muscle was normal. Gross lesions were not seen in 45 fish (14 to $66 \%$ of fish) administered zoospores (Table 1); however, several of these fish had insidious granulomas (see 'Histopathology').

\section{Aqueous exposures}

At the termination of the experiment, $64 \%$ of fish in the net-stress treatment exhibited multiple ulcerous lesions. Four fish that exhibited diffuse reddening of the skin died early, within 1 to 3 d post exposure. At termination, $14 \%$ of fish in the untraumatized challenge exhibited single focal $(5 \times 15 \mathrm{~mm})$ ulcerous lesions (Table 2$)$, and only $11 \%$ had died. Two fish exhibiting diffuse reddening of the skin died between 2 and $5 \mathrm{~d}$ post-exposure, probably of unrelated causes. The other 2 fish, exhibiting focal ulcerous lesions, died at 26 and $27 \mathrm{~d}$ post-exposure respectively (Table 2). None of the control fish died or developed lesions during the experiment.

\section{Histopathology}

Inoculation study

The tissues from 17 moribund ulcerated fish collected between 13 and 36 d p.i. exhibited deep pene- 

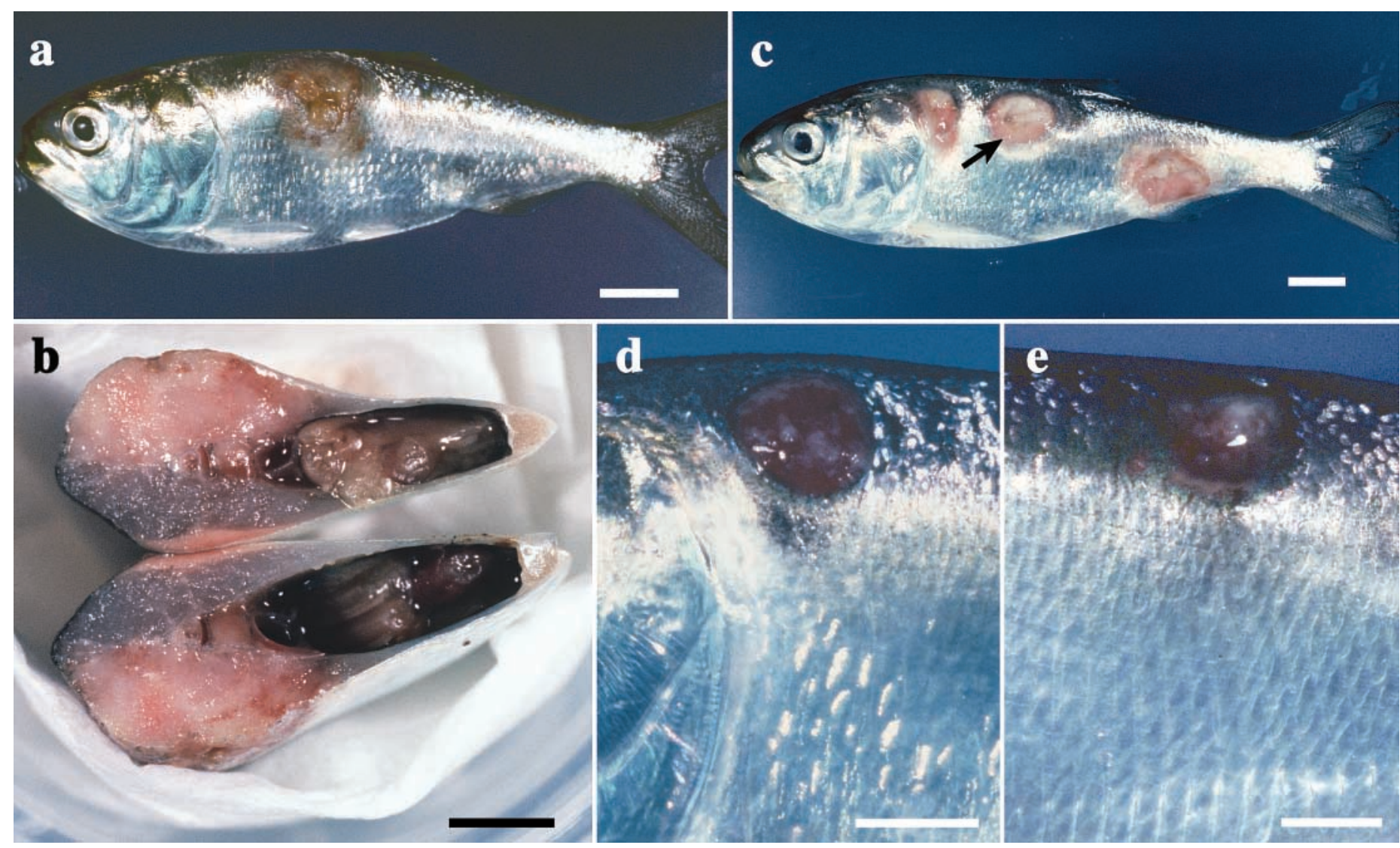

Fig. 4. Brevoortia tyrannus. Gross pathology: (a) Ulcerous lesion at the injection site at 14 d post-injection (p.i.) (1 zoospore per fish) (scale bar = $10 \mathrm{~mm}$ ). (b) Cut appearance through lesion of fish from (a) (scale bar $=5 \mathrm{~mm}$ ). (c) Multiple ulcerous lesions, 1 involving the vent (10 zoospore treatment at $26 \mathrm{~d}$ p.i.). Primary injection site is shown (arrow) (scale bar $=10 \mathrm{~mm}$ ). (d) Early stage of tissue repair process exhibiting raised, shiny red, granular, and gritty appearance (10 zoospores treatment at $37 \mathrm{~d}$ p.i.) (scale bar $=5 \mathrm{~mm}$ ). (e) Advanced stage of tissue repair process exhibiting concave, translucent, and smooth appearance (1 zoospore treatment at $37 \mathrm{~d}$ p.i.) (scale bar $=5 \mathrm{~mm})$

tration by hyphae, causing necrosis of nearly half of the left flank (Fig. 5a; Table 3). In 15 fish, the muscle tissue on the right flank opposite the injection site was invaded by hyphae. In 12 fish, the kidney was invaded, and in 1 fish the liver was affected. Granulomas were also observed in the spinal cord in 4 fish (Fig. 5b) as well as in the areolar connective tissue between the spinal cord and neural arch in 8 fish. In addition, isolated macrophages were commonly observed within the lesions (Fig. 5b). Granulation tissue, an indication of tissue repair, was evident in 3 moribund fish (2 with 100 zoospores and 1 with 5 zoospores) between 24 to $36 \mathrm{~d}$ p.i.

Histopathologically, 13 fish that survived inoculation with zoospores (37 d p.i.) exhibited tissue repair (Table 3 ). These fish exhibited relatively less hyphal invasion of the tissues (kidney, uninjected flank, spinal cord and the areolar connective tissue) compared to those of moribund fish. In 4 fish, the surface of the lesion was characterized by a granular appearance; internally, there were prominent granu-

Table 3. Brevoortia tyrannus. Number of inoculated fish exhibiting hyphae of Aphanomyces invadans invading soft tissues. Moribund fish were collected 13 to $36 \mathrm{~d}$ post-injection (p.i.) and surviving fish with tissue repair or without gross lesions were collected at $37 \mathrm{~d}$ p.i. Right-side muscle is skeletal muscle on the right flank opposite to the injection site, spinal cord is within the parenchyma of the spinal cord, and areolar connective tissues (CT) are between spinal cord and neural arch

\begin{tabular}{|lrrcccc|}
\hline & $\mathrm{n}$ & Kidney & $\begin{array}{c}\text { Right-side } \\
\text { muscle }\end{array}$ & $\begin{array}{c}\text { Spinal } \\
\text { cord }\end{array}$ & $\begin{array}{c}\text { Areolar } \\
\text { CT }\end{array}$ & Liver \\
\hline Moribund & 17 & 12 & 15 & 4 & 8 & 1 \\
$\begin{array}{l}\text { Surviving with } \\
\text { tissue repair }\end{array}$ & 13 & 1 & 3 & 0 & 1 & 0 \\
$\begin{array}{l}\text { Surviving without } \\
\text { lesions }\end{array}$ & 45 & 2 & 0 & 0 & 0 & 0 \\
\hline
\end{tabular}



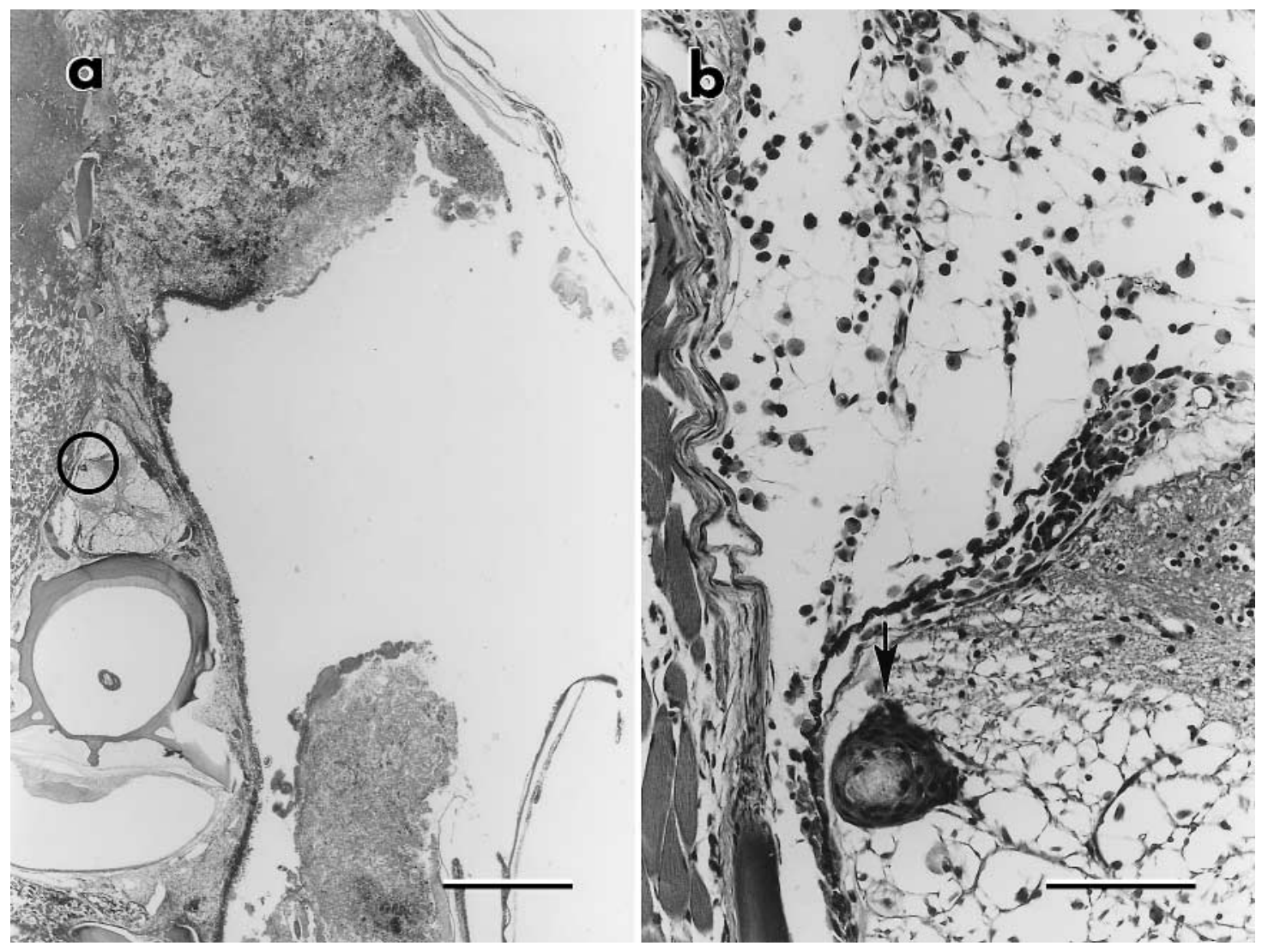

Fig. 5. Brevoortia tyrannus. Histological sections of menhaden injected with zoospores sampled at $22 \mathrm{~d}$ post-injection, moribund fish. (a) Sloughed skeletal muscle, 1 zoospore treatment (H\&E; scale bar $=1500 \mu \mathrm{m})$. (b) Higher magnification of (a) in circled area showing granuloma (arrow) in the spinal cord and isolated macrophages with pseudopodia along with eosinophilic granular cells infiltrating between the spinal cord and neural arch $(\mathrm{H} \& \mathrm{E} ;$ scale bar $=200 \mu \mathrm{m})$

lomas composed of 4 to 5 layers of epithelioid cells (Fig. 6a). The innermost epithelioid cells had strongly eosinophilic cytoplasm and nuclear pycnosis. Degenerating oomycetous hyphae were detectable as basophilic bodies within the core of the granulomas. This stage of tissue repair exhibited well-organized scaffolding of vascularization (Fig. 6b), a replacement of lost muscle tissues with granulation tissues, and a proliferation of fibrocytes (Fig. 6c). Within the lesion, leucocytic infiltration, including eosinophilic granular cells (EGCs; Fig. 6c), macrophages and lymphoid cells, was prominent.

A possibly more advanced stage of tissue repair was observed in 9 fish and was characterized by a thickening of epithelial and dermal cells of the skin (Fig. 6d) with scale regeneration (Fig. 6e). Remodeling of the skeletal muscles with regenerating myofibrils was apparent by the basophilic appearance of the cytoplasm (Fig. 6d). The lesion was also characterized by the lack of overt necrotic space, but elongate, ovoid granulomas (2 to 3 layers of epithelioid cells) were dis- tributed sporadically along myosepta or among skeletal muscles with few to no leuycocytic infiltrations, and there were few vascularized areas (Fig. 6f). Muscle tissues adjacent to the myosepta were occasionally accompanied by collagen fibrils (MT). Macrophage aggregates were also sporadically observed in these lesions.

Thirty-nine percent of the fish that were inoculated with Aphanomyces invadans exhibited no gross lesions (Table 3). Histological samples were taken from 2 anterior and 2 posterior portions around the inoculation site of these 45 fish $(39 \%)$. Granulomas were detected in the skeletal muscle of 18 fish (Table 1). Granulomatous inflammation was similar to that observed in the lesions undergoing the more advanced stage of tissue repair. The granulomas were most often detected in the anterior portion of the inoculated area $(67 \%)$, with their detection decreasing in the 3 posterior sections $(50,17$, and $6 \%$ respectively), which was a result of the inoculation. Invasiveness to other organs was limited in this group; only 2 fish exhibited minor 


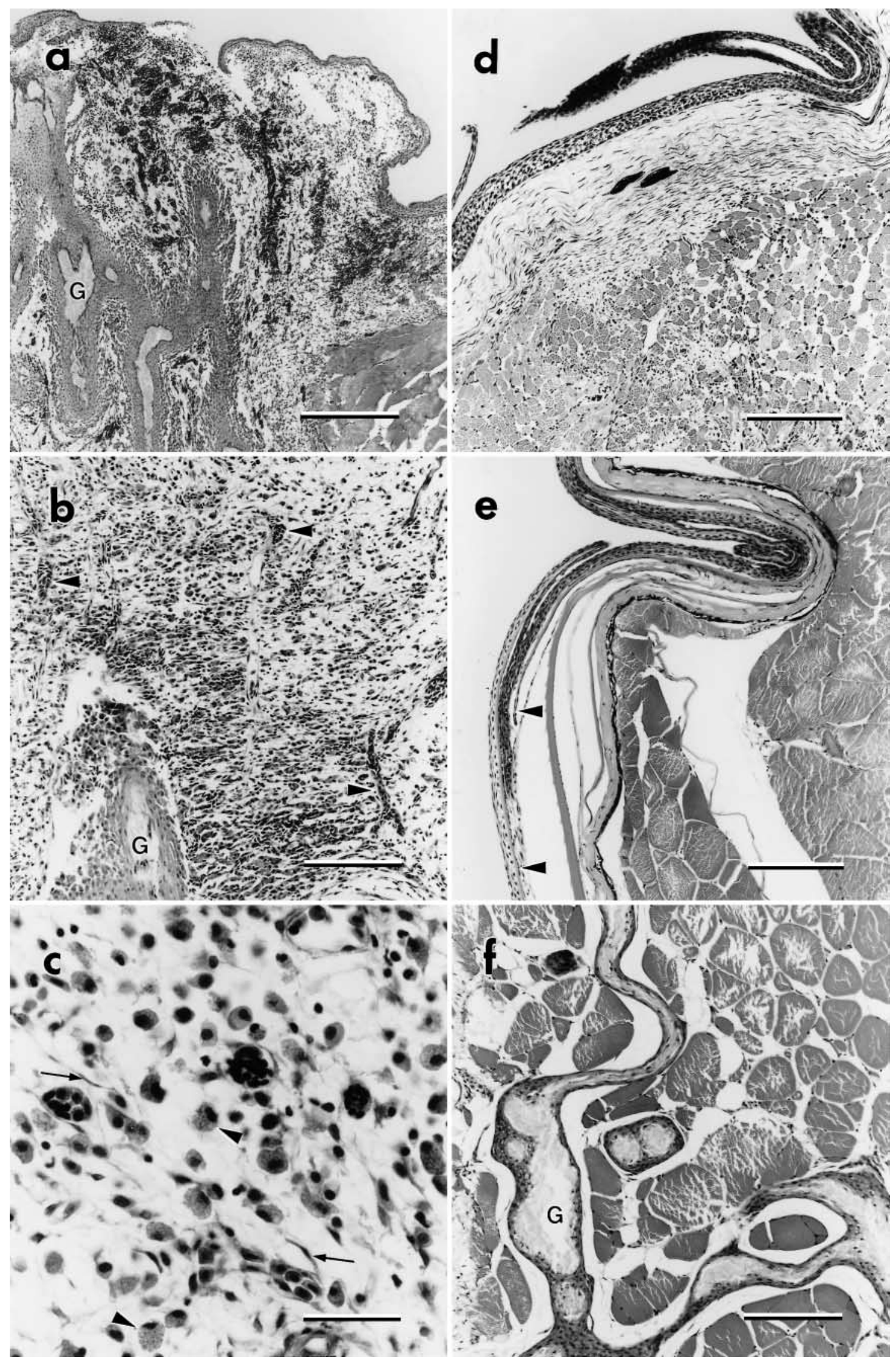


Fig. 6. Brevoortia tyrannus. Histological sections of menhaden injected with zoospores sampled at 37 d post-injection exhibiting tissue repair at early $(\mathrm{a}-\mathrm{c})$ and late $(\mathrm{d}-\mathrm{f})$ stages, 100 zoospores treatment. (a) Granular appearance at the skin surface and welldeveloped granulomas $(G)$ in a confined area $\left(H \& E_{\text {; }}\right.$ scale bar $\left.=500 \mu \mathrm{m}\right)$. (b) Well-organized capillary vascularization (arrowheads) and granular tissues (H\&E; scale bar $=100 \mu \mathrm{m})$. (c) Higher magnification showing eosinophilic granular cells (EGCs; arrowheads) and fibrocytes (arrows) filling the lesion area H\&E; scale bar $=50 \mu \mathrm{m}$ ). (d) Thickening of epithelial cells and subdermal layer of the skin tissue and remodeling of the skeletal muscle with regenerated myocytes (H\&E; scale bar $=200 \mu \mathrm{m})$. (e) Scale regeneration (arrowheads) (H\&E; scale bar $=100 \mu \mathrm{m})$. (f) Elongated granuloma in the deep skeletal muscle, not exhibiting surrounding inflammatory cells (scale bar $=100 \mu \mathrm{m}$ )

granuloma formation in the kidney (Table 3). After $37 \mathrm{~d}$ p.i., the sham-injected controls exhibited clinically healthy skeletal muscle tissues with no obvious pathology at the site of inoculation.

\section{Aqueous exposures}

The pathology arising from aqueous exposures has been described for the early (5 $\mathrm{d}$ post-exposure) and middle (21 and $27 \mathrm{~d}$ post-exposure) stages of infection (Kiryu et al. 2002). Ulcerous fish collected at $27 \mathrm{~d}$ postexposure in the present aqueous exposure exhibited identical histopathological findings to those described by Kiryu et al. (2002).

Scanning electron microscopy of menhaden exposed to secondary zoospores indicated that the oomycete could encyst on the intact epidermis of the fish (Fig. 7). Germination tubes were evident and apparently penetrated through the epidermal tissues. Adjacent intact epidermal cells appeared normal, but infected cells may have lost their surficial integrity, presumably as a result of penetration of the oomycete hyphae.

\section{DISCUSSION}

Aphanomyces invadans was highly pathogenic to Atlantic menhaden in this study. The calculated $\mathrm{LD}_{50}$ was 9.7 zoospores per fish, and a single zoospore was capable of initiating an ulcer that could lead to fish mortality. All but one of the menhaden that developed ulcers died in the inoculation experiment. Further, multi-focal lesions developed within fish inoculated with an estimated 1 zoospore, indicating that 1 zoospore can potentially give rise to multiple lesions, thus confirming the observation that the hyphae travel along the myosepta (Kiryu et al. 2002).

The marked pathogenicity of Aphanomyces invadans may result from its highly invasive nature. Hyphae were observed penetrating into the spinal cord, kidney tissues, liver, and uninoculated quadrant of infected menhaden. This invasiveness into the soft tissues has been described from both laboratory infections with ayu Plecoglossus altivelis (Wada et al. 1996), and in field-caught menhaden (Noga \& Dykstra 1986,
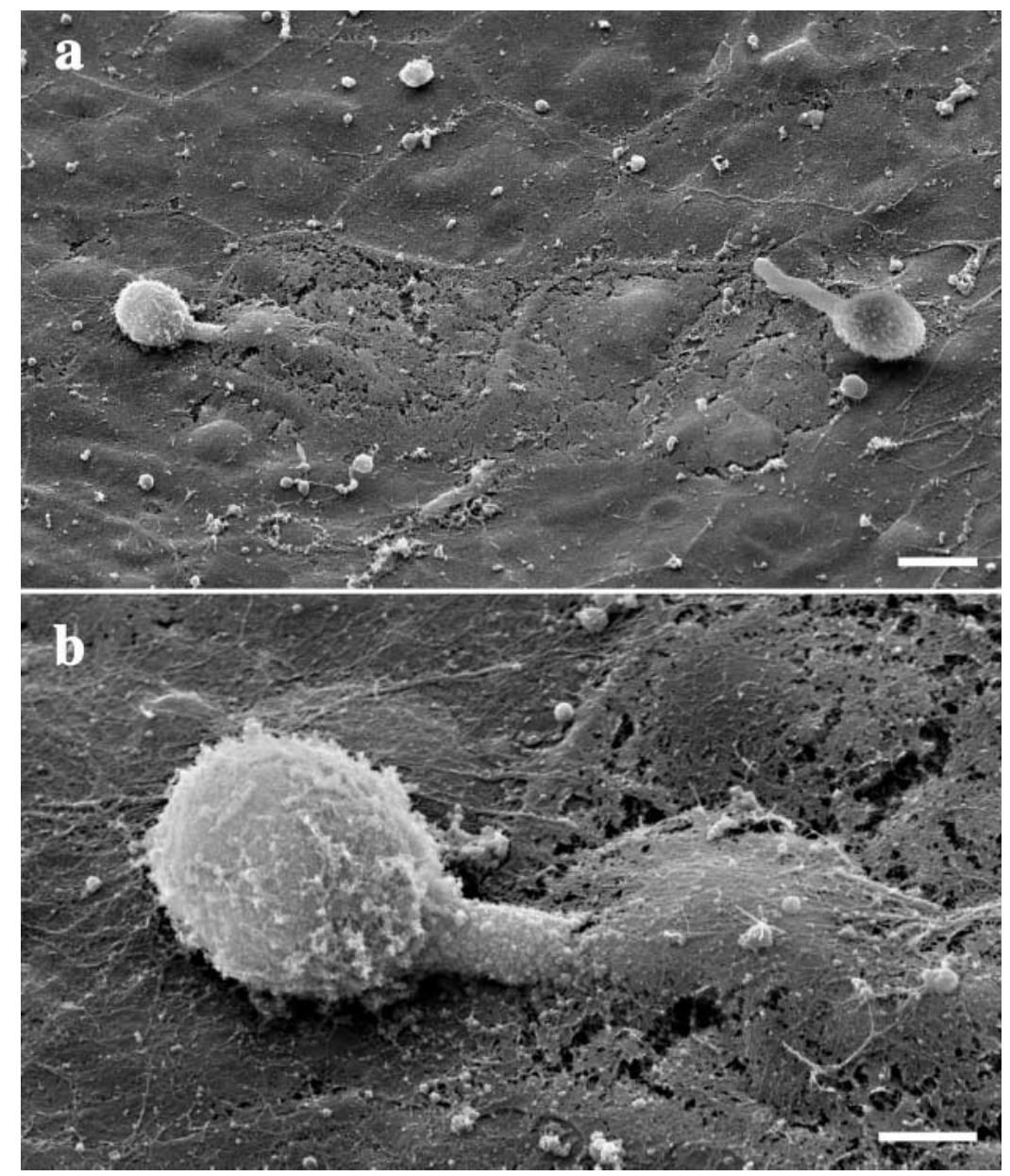

Fig. 7. Aphanomyces invadans. (a) Scanning electron micrograph of secondary zoospore with protruding germination tube starting to invade deeper to the menhaden skin (scale bar $=6 \mu \mathrm{m}$ ). (b) Detail of secondary zoospore with penetration of germination tube firmly into the skin epithelium (scale bar $=1.5 \mu \mathrm{m}$ ) 
Noga et al. 1988, Blazer et al. 1999). In experimentally infected ayu, hyphal growth and invasion into the trunk muscles and soft tissues was rapid, with the hyphal mass in the trunk muscle doubling every $10 \mathrm{~d}$ (Wada et al. 1996). Frank ulcers in naturally infected menhaden from the field exhibited inflammmation and necrosis of the visceral organs into which the hyphae had penetrated (Blazer et al. 1999). In naturally infected goldfish Carassius auratus Miyazaki \& Egusa (1972) found that if the initial infection was at the operculum (head) or caudal (trunk), then hyphae invaded the brain and spinal cord, and the size of the granuloma was usually smaller than that observed in other organs.

In North Carolina, fish kills involving hundreds of thousands of menhaden have reported prevalences of ulcerative lesions of up to 90\% (Burkholder et al. 1992, 1995). Given (1) that Aphanomyces invadans is highly pathogenic in laboratory exposures (Kiryu et al. 2002, present study), (2) that it is capable of acting as a primary pathogen (see below), (3) that the water mould causes major mortalities in SE Asia as EUS (Lilley et al. 1998), and (4) that stressed (net-handled) fish are more susceptible to the development of lesions and mortalities (Kiryu et al. 2002, present study), we speculate that A. invadans is a significant causal or contributory factor in the large fish kills of menhaden observed in estuaries along the eastern US coast. Further, we speculate that the presence of lesions on dead and dying menhaden involved in large-scale fish kills implicates $A$. invadans as the causal agent, and as such, these kills may be inadvertently correlated with confounding factors such as Pfiesteria piscicida (Burkholder et al. 1995, 2001, Burkholder \& Glasgow 1997) or hypoxia (Paerl et al. 1998). Thus, a school of menhaden exposed to a highly invasive, highly pathogenic water mould with a high morbidity rate, further compromised by adverse and long-term environmental stressors (i.e. extensive and long-term hypoxia; Paerl et al. 1998, Glasgow et al. 2001), may become infected and succumb to the ulcerative disease.

Menhaden inoculated with Aphanomyces invadans experienced 3 outcomes. Fish developed either (1) ulcers and died, (2) internal granulomas without frank ulcers and survived, or (3) clinical signs of tissue repair and survived. Many menhaden inoculated with the oomycete did not develop ulcers; rather, they possessed single or multifocal granulomas (21 to 100\% of fish in various treatments). The presence of internal granulomas without overt lesions probably resulted from the artificial nature of exposure (inoculation). Subcutaneous inoculation as the route of infection was necessary to achieve controlled, environmentally realistic doses. However, ulcers more likely develop from the 'outside-in' process of infection (Fig. 7) as opposed to lesions artificially induced via the 'inside-out' process of inoculation (see Law 2001).

High prevalences of infection with Aphanomyces invadans reportedly occur in years with high rainfall, or in regions with low salinities (Callinan et al. 1989, Levine et al. 1990, Noga 1993, Lilley et al. 1998). A. invadans has a low salinity tolerance and will not grow well in salinities above 15 psu (Dykstra et al. 1986, Levine et al. 1990, Blazer et al. 2002). The secondary zoospores of $A$. invadans lose their infectivity above 4 to 6 psu (Fraser et al. 1992, Lilley et al. 1998, Kiryu et al. 2002), indicating that infections must occur below 4 psu (Kiryu et al. unpubl. data). Rainfall is thought to contribute to epizootics of EUS by (1) reducing salinity to allow the oomycete to sporulate, (2) inducing sublethal exposure to acidified runoff, resulting in epidermal necrosis and exposure of the dermis (Sammut et al. 1996), and (3) reducing dissolved oxygen to $<1 \mathrm{mg} \mathrm{l}^{-1}$ with concomitant damage to the epidermis (Plumb et al. 1976). However, few of these environmental factors have been explored in relation to the development of UM in menhaden.

We have demonstrated that the WIC isolate of Aphanomyces invadans is a primary pathogen of menhaden. That is, the oomycete can attach to, germinate on, and invade the intact epidermis of the fish. By contrast, outbreaks of red spot disease (RSD) in cultured fishes in Australia have been shown to occur only following skin injury (Callinan 1995). Previous challenge experiments with strains of A. invadans from SE Asia have indicated that zoospores attach to the dermis, not the epidermis, before invasion; and, therefore, the oomycete is a secondary invader requiring a portal of entry (Lilley et al. 1998). In salmonids, Saprolegnia spp. are often considered secondary invaders and have been correlated with predisposing factors such as induced stress (e.g. Pottinger \& Day 1999), handling stress or trauma to the skin, but primary cases of saprolegniasis have been reported (Roberts 2001). While the WIC strain of $A$. invadans is highly infectious given a portal of entry, bath challenges on untraumatized fish indicate that it may not require a portal for infection to occur. Clearly, the relationships between integumental damage, exposure, development of lesions, and fish mortality require further study.

Menhaden have a strong cellular response to infection by Aphanomyces invadans. Granuloma formation can occur in as little as $5 \mathrm{~d}$ after administration of zoospores in both bath exposure and subcutaneous injection (Kiryu et al. 2002). In the present study, a subset of infected animals did not develop ulcers; rather, they had internal granulomas with adjacent tissues undergoing classical signs of tissue repair (e.g. Roberts 1975, 2001, Iger \& Abraham 1990). In comparison, Callinan et al. (1989) observed wound healing in sea 
mullet Mugil cephalus naturally infected with $A$. invadans, as did Chinabut et al. (1995) in snakehead Channa striatus after challenge with $A$. invadans zoospores. However, we did not find evidence of tissue repair in fish exposed to zoospores in bath challenges. The bath-exposed fish, especially those in the netstress treatment, exhibited multi-focal infection patterns along the myosepta. It is possible that these fish were less likely to recover from multiple lesions than those with single localized lesions.

In conclusion, we have shown that Aphanomyces invadans is a highly infectious, highly pathogenic, highly invasive primary pathogen in menhaden. Whereas the pathogen is facilitated by a portal of entry, such a portal is not required for infection to occur.

Acknowledgements. This research was funded by the EPA ECOHAB Grant Program \#R-828225, the US Geological Survey's Chesapeake Bay Initiative, and the Virginia Institute of Marine Science's Pfiesteria Initiative. At VIMS, we thank Pat Blake, David Zwerner, Kyle Hayes, RaeMarie Johnson, Christopher Squyars, Alynda Miller, Dana Booth and Martha Rhodes. At the US Geological Survey, we thank Christine Densmore and Deborah Cartwright. David Gauthier (VIMS) and Christine Densmore (USGS) critically reviewed the manuscript. We are indebted to John Jacobs at the University of Maryland for his help in providing experimental fish. This is Virginia Institute of Marine Science Contribution \#2500.

\section{LITERATURE CITED}

Blazer VS, Vogelbein WK, Densmore CL, May EB, Lilley JH, Zwerner DE (1999) Aphanomyces as a cause of ulcerative skin lesions of menhaden from Chesapeake Bay tributaries. J Aquat Anim Health 11:340-349

Blazer VS, Lilley J, Schill WB, Kiryu Y, Densmore CL, Panyawachira V, Chinabut S (2002) Aphanomyces invadans in Atlantic menhaden along the east coast of the United States. J Aquat Anim Health 14:1-10

Burkholder JM, Glasgow HB Jr (1997) Pfiesteria piscicida and other Pfiesteria-like dinoflagellates: behavior, impacts, and environmental controls. Limnol Oceanogr 42:1052-1075

Burkholder JM, Noga EJ, Hobbs CW, Glasgow HB Jr (1992) New 'phantom' dinoflagellate is the causative agent of major estuarine fish kills. Nature 358:407-410

Burkholder JM, Glasgow HB Jr, Hobbs CW (1995) Fish kills linked to a toxic ambush-predator dinoflagellate: distribution and environmental conditions. Mar Ecol Prog Ser 124: 43-61

Burkholder JM, Glasgow HB, Deamer-Melia N (2001) Overview and present status of the toxic Pfiesteria complex (Dinophyceae). Phycologia 40:186-214

Callinan RB, Fraser GC, Virgona JL (1989) Pathology of red spot disease in sea mullet, Mugil cephallus L., from eastern Australia. J Fish Dis 12:467-479

Callinan RB, Paclibare JO, Bondad-Reantaso MG, Chin JC, Gogolewski RP (1995) Aphanomyces species associated with epizootic ulcerative syndrome (EUS) in the Philippines and red spot disease (RSD) in Australia: preliminary comparative studies. Dis Aquat Org 21:233-238

Cantor AB (1997) Extending SAS survival analysis techniques for medical research. SAS Institute, Cary, NC

Catap ES, Munday BL (1998) Effects of variations of water temperature and dietary lipids on the expression of experimental epizootic ulcerative syndrome (EUS) in sand whiting, Sillago ciliata. Fish Pathol 33:327-335

Chinabut S, Roberts RJ, Willoughby GR, Pearson MD (1995) Histopathology of sankehead, Channa striatus (Bloch), experimentally infected with the specific Aphanomyces fungus associated with epizootic ulcerative syndrome (EUS) at different temperatures. J Fish Dis 18:41-47

Dykstra MJ, Noga EJ, Levine JF, Moye DW, Hawkins JH (1986) Characterization of the Aphanomyces species involved with ulcerative mycosis (UM) in menhaden. Mycologia 78:664-672

Dykstra MJ, Levine JF, Noga EJ, Hawkins JH, Gerdes P, Hargis WJ Jr, Grier HJ, Te Strake D (1989) Ulcerative mycosis: a serious menhaden disease of the southeastern coastal fisheries of the United States. J Fish Dis 12: $175-178$

Egusa S, Masuda N (1971) A new fungal disease of Plecoglossus altivelis. Fish Pathol 6:41-46

Fraser GC, Callinan RB, Calder LM (1992) Aphanomyces species associated with red spot disease: an ulcerative disease of estuarine fish from eastern Australia. J Fish Dis 15: 173-181

Glasgow HB, Burkholder JM, Morton SL, Springer J (2001) A second species of icthyotoxic Pfiesteria (Dinamoebales, Dinophyceae). Phycologia 40:234-245

Hargis WJ Jr (1985) Quantitative effects of marine diseases on fish and shellfish populations. Trans N Am Wildl Nat Resour Conf 50:608-640

Hatai K, Egusa S, Takahashi S, Ooe K (1977) Study on the pathogenic fungus of mycotic granulomatosis. I. Isolation and pathogenecity of the fungus from cultured ayu infected with the disease. J Fish Pathol 12:129-133

Iger Y, Abraham M (1990) The process of skin healing in experimentally wounded carp. J Fish Biol 36:421-437

Kiryu Y, Shields JD, Vogelbein WK, Zwerner DE, Kator H, Blazer VS (2002) Induction of skin ulcers in Atlantic menhaden by injection and aqueous exposure to the zoospores of Aphanomyces invadans. J Aquat Anim Health 14:11-24

Law M (2001) Differential diagnosis of ulcerative lesions in fish. Environ Health Perspect 109:681-686

Lee ET (1992) Statistical methods for survival analysis, 2nd edn. John Wiley \& Sons, New York

Levine JF, Hawkins JH, Dykstra MJ, Noga EJ, Moye DW, Cone RS (1990) Epidemiology of ulcerative mycosis in Atlantic menhaden in the Tar-Pamlico River Estuary, North Carolina. J Aquat Anim Health 2:162-171

Lilley JH, Roberts RJ (1997) Pathogenecity and culture studies comparing the Aphanomyces involved in epizootic ulcerative syndrome (EUS) with other similar fungi. J Fish Dis 20:135-144

Lilley JH, Callinan RB, Chinabut S, Kanchanakhan S, MacRae IH, Phillips MJ (1998) Epizootic ulcerative syndrome (EUS) technical handbook. Aquatic Animal Health Research Institute, Bangkok

Luna LG (1968) Manual of histologic staining methods of the Armed Forces Institutes of Pathology, 3rd edn. McGrawHill, New York

Miyazaki T, Egusa S (1972) Studies on mycotic granulomatosis in fresh water fishes. I. Mycotic granulomatosis in goldfish. Fish Pathol 7:15-25

Miyazaki T, Egusa S (1973a) Studies on mycotic granulomatosis in fresh water fishes. II. Mycotic granulomatosis in Ayu, Plecoglossus altivelis. Fish Pathol 7:125-133

Miyazaki T, Egusa S (1973b) Studies on mycotic granulo- 
matosis in fresh water fishes. III. Mycotic granulomatosis in blue-gill. Fish Pathol 8:41-43

Miyazaki T, Egusa S (1973c) Studies on mycotic granulomatosis in fresh water fishes. IV. Mycotic granulomatosis in wild fishes. Fish Pathol 8:44-47

Noga EJ (1993) Fungal diseases of marine and estuarine fishes. In: Couch JA, Fournie JW (eds) Pathobiology of marine and estuarine organisms. CRC Press, Boca Raton, FL, p 85-109

Noga EJ, Dykstra MJ (1986) Oomycete fungi associated with ulcerative mycosis in menhaden, Brevoortia tyrannus (Latrobe). J Fish Dis 9:47-53

Noga EJ, Levine JF, Dykstra MJ, Hawkins JH (1988) Pathology of ulcerative mycosis in Atlantic menhaden Brevoortia tyrannus. Dis Aquat Org 4:189-197

Noga, EJ, Wright JF, Levine JF, Dykstra MJ, Hawkins JH (1991) Dermatological diseases affecting fishes of the TarPamlico Estuary, North Carolina. Dis Aquat Org 10:87-92

Noga EJ, Khoo L, Stevens JB, Fan Z, Burkholder JM (1996) Novel toxic dinoflagellate causes epidemic disease in estuarine fish. Mar Pollut Bull 32(2):219-224

Paerl HW, Pinckney JL, Fear JM, Peierls BL (1998) Ecosystem responses to internal and watershed organic matter loading: consequences for hypoxia in the eutrophying Neuse River Estuary, North Carolina, USA. Mar Ecol Prog Ser 166:17-25

Pottinger TG, Day JG (1999) A Saprolegnia parasitica challenge system for rainbow trout: assessment of Pyceze as an anti-fungal agent for both fish and ova. Dis Aquat Org

Editorial responsibility: David Bruno,

Aberdeen, Scotland, UK
36:129-141

Plumb JA, Grizzle JM, Defigueiredo J (1976) Necrosis and bacterial infection in channel catfish (Ictalurus punctatus) following hypoxia. J Wildl Dis 12:247-253

Roberts RJ (1975) The effects of temperature on diseases and their hsitopathological manifestations in fish. In: Ribelin WE, Migaki G (eds) Pathology of fishes. University of Wisconsin Press, Madison, p 477-496

Roberts RJ (2001) Fish Pathology, 3rd edn. WB Saunders, London

Roberts RJ, Willoughby LG, Chiabut S (1993) Mycotic aspects of epizootic ulcerative syndrome (EUS) of Asian fishes. J Fish Dis 16:169-183

SAS Institute (1989) SAS/STAT user's guide, Version 6, 4th edn. SAS Institute, Cary, NC

Sammut J, White I, Melville MD (1996) Acidification of an estuarine tributary in eastern Australia due to drainage of acid sulfate soils. Mar Freshw Res 47:669-684

Wada S, Yuasa K, Rha S, Nakamura K, Hatai K (1994) Histopathology of Aphanomyces infection in dwarf gourami (Colisa lalia). Fish Pathol 29:229-237

Wada S, Rha S, Kondoh T, Suda H, Hatai K, Ishi H (1996) Histopathological comparison between ayu and carp artificially infected with Aphanomyces piscicida. Fish Pathol 31:71-80

Willoughby LG, Roberts RJ (1994) Improved methodology for isolation of the Aphanomyces fungal pathogen of epizootic ulcerative syndrome (EUS) in Asian fish. J Fish Dis 17:541-543

Submitted: July 13, 2002; Accepted: December 30, 2002 Proofs received from author(s): March 20, 2003 